\title{
ANALISIS PEMBEBANAN BELT CONVEYOR MENGGUNAKAN MOTOR INDUKSI 3 FASE 1,5 KW DAN VSD SEBAGAI SPEED CONTROLLER
}

\author{
Sigi Syah Wibowo ${ }^{1}$, Abdul Manaf $^{2}$, dan Tresna Umar ${ }^{3}$ \\ 1,2,3 Jurusan Teknik Elektro, Politeknik Negeri Malang, Indonesia \\ ${ }^{1}$ sigi.wibowo@polinema.ac.id, 2amanaf.choedhori@gmail.com,,33 pak_tresna@yahoo.co.id \\ (Artikel diterima: Oktober 2019, direvisi: September 2019, diterima untuk terbit: Januari 2020)
}

\begin{abstract}
Abstrak - Pendistribusian bahan baku maupun hasil produksi pada dunia industri dilakukan oleh alat pemindah bahan, seperti conveyor. Conveyor memiliki beberapa jenis, yaitu belt conveyor, screw conveyor, apron conveyor, dan pneumatic conveyor. Belt conveyor merupakan peralatan angkut material secara horizontal dengan cara mentransport muatan berupa unit maupun curah di atas sabuk yang digerakkan oleh drive / head pulley yang terhubung dengan puli transmisi, gear box, dan motor induksi 3 fasa 1,5 kW. Pengaturan kecepatan pada belt conveyor dilakukan oleh VSD dengan mode pengoperasian $\mathrm{nLd}$ melalui perubahan frekuensi yang dibutuhkan. Perencanaan dan pembuatan modul pembebanan belt conveyor memiliki kapasitas 6 ton/jam $(100 \mathrm{~kg} / \mathrm{menit})$ dengan kecepatan $0,05 \mathrm{~m} / \mathrm{s}$ dan diharapkan dapat digunakan untuk kegiatan praktikum mahasiswa di Laboratorium Gedung AL 1.01 Politeknik Negeri Malang. Rancang bangun modul pembebanan belt conveyor ini bertujuan untuk mengetahui perancangan, pembuatan, dan pengujian belt conveyor menggunakan motor induksi 3 phasa $1,5 \mathrm{~kW}$ dan VSD sebagai speed controller. Selain itu juga mengetahui pengaruh variasi beban dan frekuensi terhadap kecepatan laju belt conveyor. Sehingga dengan model pembebanan tersebut dapat diketahui karakteristik modul berupa arus input motor, daya input, kecepatan motor, slip, efisiensi, dan kecepatan belt conveyor.
\end{abstract}

Kata kunci: motor, VSD, speed controller, efisiensi

\section{Pendahuluan}

Pendistribusian bahan baku maupun produk di dalam perusahaan dilakukan oleh alat-alat angkut yang sudah dirancang sesuai kebutuhan guna mempermudah proses pemindahan bahan baku maupun produk. Pada pabrik-pabrik bagian pengangkutan dan pemindahan serta pendistribusian, keberadaan mesin pemindah bahan memegang peranan penting. Penggunaan alat pemindah bahan yang sesuai akan sangat membantu dalam kelancaran produksi. Berdasarkan prinsip pengangkutannya, alat transportasi bahan dibedakan menjadi dua macam, yaitu: prinsip pengangkutan horizontal, disebut conveyor dan prinsip pengangkutan vertikal, disebut elevator. Dalam hal ini, peneliti akan melakukan penelitian tentang prinsip pengangkutan secara horizontal, yaitu conveyor. Dengan menggunakan conveyor, perusahaan mampu menghemat biaya produksi dan meningkatkan hasil produksi secara signifikan.

Prinsip kerja belt conveyor adalah mentransport material yang ada di atas belt (sabuk ban berjalan), belt digerakkan oleh drive / head pulley dengan menggunakan motor penggerak. Agar conveyor dapat berjalan sesuai dengan kebutuhan maka dibutuhkan penggerak yang berupa motor induksi. Untuk mengatur kecepatan putar suatu motor induksi salah satu solusinya dengan menggunakan Variable Speed Drive (VSD) yang bekerja dengan mengubah frekuensi sesuai dengan yang diinginkan atau berdasarkan dengan kebutuhan beban.

Desain dan pembuatan modul pembebanan dengan menggunakan conveyor difokuskan untuk mengetahui prinsip kerja conveyor dan diharapkan berguna untuk kegiatan praktikum mahasiswa di Laboratorium Elektronika Daya Gedung AL 1.01 Politeknik Negeri Malang.

\section{Tinjauan Pustaka}

\section{A. Belt Conveyor.}

Belt conveyor atau sabuk konveyor adalah pesawat pengangkut yang digunakan untuk memindahkan muatan dalam bentuk satuan atau tumpahan, dengan arah horizontal atau membentuk sudut dakian/inklinasi dari suatu sistem operasi yang satu ke sistem operasi yang lain dalam suatu line proses produksi, yang menggunakan sabuk sebagai penghantar muatannya. Belt Conveyor pada dasarnya merupakan peralatan yang cukup sederhana dan secara intensif digunakan disetiap cabang industri. Alat tersebut terdiri dari sabuk yang tahan terhadap pengangkutan benda padat. Sabuk yang digunakan pada belt conveyor ini dapat dibuat dari berbagai jenis bahan misalnya dari karet, plastik, kulit ataupun logam yang tergantung dari jenis dan sifat bahan yang akan diangkut.

\section{B. Prinsip Kerja Belt Conveyor.}

Prinsip kerja belt conveyor adalah mentransport material yang ada di atas belt, dimana umpan atau inlet pada sisi tail dengan menggunakan chute dan setelah sampai di head material ditumpahkan akibat belt berbalik arah. Belt digerakkan oleh drive/head pulley dengan menggunakan motor penggerak. Head pulley menarik belt dengan prinsip adanya gesekan antara permukaan drum dengan belt, sehingga kapasitasnya tergantung gaya gesek tersebut.

Bagian penggerak head pulley dengan menggunakan motor listrik yang diteruskan ke gear reducer dengan coupling diteruskan kembali ke head pulley. Kelangkapan alat ini ada yang dipasangi holdback / back stop untuk mencegah belt mundur saat berhenti ketika ada muatan, ini digunakan pada belt conveyor yang menanjak. Pada bagian bawah head pulley biasanya dilengkapi dengan pembersih / belt cleaner, fungsinya untuk membersihkan material yang menempel pada belt setelah material dituangkan. 


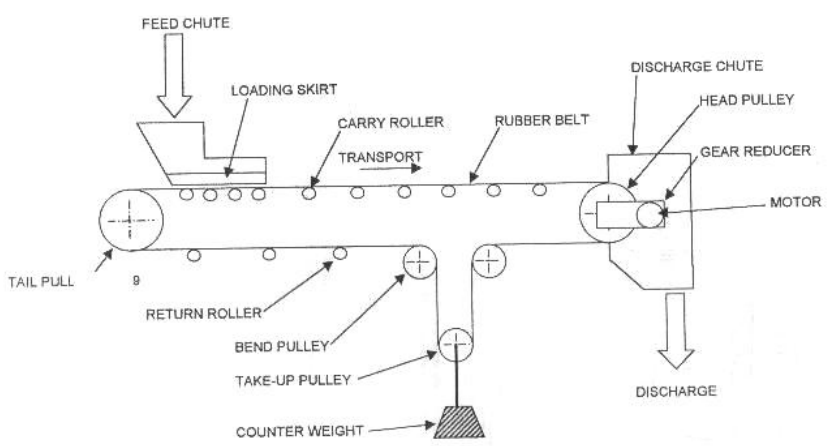

Gambar 1. Bagian-bagian belt conveyor.

\section{Karakteristik Motor Induksi 3 Fase.}

Karakteristik motor listrik menunjukkan kinerja motor tersebut dalam berbagai kondisi operasi. Karakteristik motor listrik yang utama, yang perlu diperhatikan adalah :

1. Karakteristik torsi-arus

2. Karakteristik kecepatan-arus

3. Karakteristik torsi-kecepatan.

Torsi di bangkitkan pada poros motor atau mesin penggerak dengan kecepatan putar n. Dari kedua besaran ini, maka dapat diketahui daya mekanis motor atau mesin penggerak tersebut. Kecapatan putaran motor $\mathrm{n}$ adalah jumlah revolusi untuk suatu periode waktu tertentu. Kecepatan putaran motor diukur dalam satuan revolusi per menit (rpm) atau revolusi per detik (rps). Kecepatan putaran motor listrik umumnya menggunakan satuan revolusi per menit (rpm). Untuk pengukuran torsi dapat digunakan tongkat penyeimbang, dimana hasil kali antara gaya dan panjang dari lengan penyeimbang merupakan torsi yang dihasilkan.

$$
T=\mathrm{Fxr}
$$

\section{Keterangan :}

$$
\begin{array}{ll}
\mathrm{T} & \text { : torsi }(\mathrm{Nm}) \\
\mathrm{F} & \text { : gaya (newton) } \\
\mathrm{r} & \text { : radius (meter) }
\end{array}
$$

Jika torsi yang searah jarum jam sama besar dengan torsi yang berlawanan arah jarum jam, maka tercapai posisi seimbang. Jika kedua torsi ini tidak seimbang, maka kedua lengan ini akan berputar ke arah torsi yang lebih besar. Torsi juga dibangkitkan oleh mesin listrik putar, dimana medan magnet membangkitkan garis gaya magnet (fluks) di dalam stator. Berdasarkan prinsip dasar motor, maka gaya yang dibangkitkan pada konduktor kumparan rotor yang dialiri arus adalah :

$$
F=\mathrm{BxIxl}
$$

Gaya ini bekerja pada konduktor yang berjarak dari titik tengah poros rotor.

\section{VSD (Variable Speed Drive).}

VSD (Variable Speed Drive) atau yang biasa disebut inverter merupakan sebuah alat yang digunakan untuk mengatur kecepatan motor dengan mengubah nilai frekuensi dan tegangan yang masuk ke motor. Pengaturan nilai frekuensi dan tegangan ini dimaksudkan untuk mendapatkan kecepatan putaran motor yang diinginkan. Memang ada banyak cara untuk mengatur atau mengurangi kecepatan motor seperti dengan menggunakan gearbox atau reducer. Namun mengatur kecepatan motor dengan VSD akan memperoleh banyak keuntungan bila dibandingkan dengan cara-cara yang lain.

Keuntungan yang diperoleh seperti:

a) Range pengaturan kecepatan dan torsi motor yang luas.

b) Akselerasi dan deselarasi dapat diatur.

c) Mempermudah proses monitoring atau pengecekan.

d) Sistem proteksi motor yang baik.

e) Mengurangi arus starting motor.

\section{E. Torsi dan Daya Motor Induksi 3 Fase.}

Torsi berhubungan dengan kemampuan motor untuk mensuplai beban mekanik. Oleh karena itu torsi (T) secara umum dapat dirumuskan sebagai berikut.

$$
T=\frac{\mathrm{P}}{\omega}
$$

$$
\begin{array}{ll}
\text { Keteranagn : } \\
\mathrm{T} & \text { : torsi }(\mathrm{Nm}) \\
\mathrm{P} & \text { : daya }(\mathrm{W}) \\
\omega r & \text { : kecepatan sudut (mekanik) dari rotor. }
\end{array}
$$

Hubungan torsi dengan perubahan kecepatan ditunjukkan pada gambar 2.2

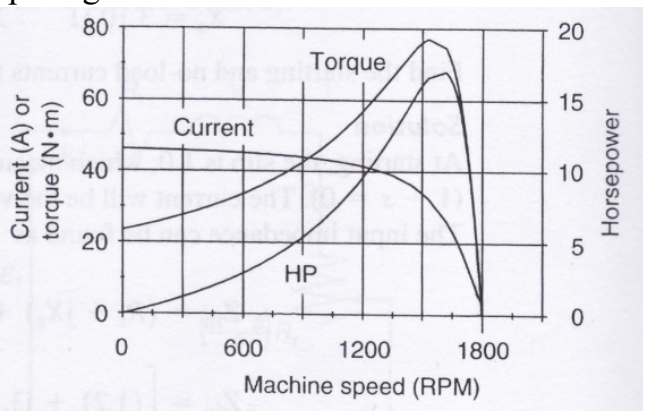

Gambar 2. Kurva karakteristik motor induksi.

Pengaturan motor induksi dapat dilakukan dengan merubah jumlah kutub atau frekuensi, jika jumlah kutub atau frekuensi berubah maka kecepatan motor induksi juga berubah. Untuk merubah kecepatan dengan merubah jumlah kutub sangatlah terbatas, karena itu yang paling luas adalah dengan cara merubah frekuensi. Semakin besar nilai frekuensi, semakin cepat putarannya. Pada frekuensi nominal dan frekuensi dibawah nominalnya, nilai torsi akan konstan walaupun bebannya berubah. Tetapi frekuensi diatas nominalnya, maka nilai torsi akan turun.
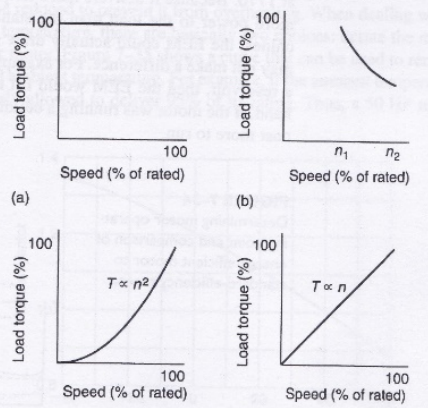

Gambar 3. Kurva torsi-kecepatan karakteristik beban

Beban berbeda memiliki persyaratan yang berbeda untuk torsi sebagai fungsi dari kecepatan. Gambar 2.3 
menggambarkan beberapa jenis beban biasa ditemui.

Bagian (a) menunjukkan torsi beban konstan secara jelas. Torsi beban konstan yang paling sering ditemui, dengan perkiraan menempatkan lebih dari $60 \%$ dari semua beban. Bagian (b) menunjukkan beban daya konstan. Daya torsi kali kecepatan, sehingga penurunan torsi kecepatan meningkat. Beban ini mungkin memerlukan torsi awal yang tinggi. Bagian (c) menunjukkan torsi beban lain yang sangat umum, yang disebut daya eksponensial ganda. Torsi sebanding dengan kuadrat kecepatannya. Perangkat ini membutuhkan torsi awal yang relatif rendah seperti pompa sentrifugal, fan, blower. Bagian (d) menunjukkan torsi yang fungsi linear dari kecepatan, sehingga torsi sebanding dengan kecepatannya.

Daya input motor,

$T=\sqrt{3} \cdot V \cdot \operatorname{In} \cdot \cos \varphi$

Efisiensi motor,

$$
\eta=\frac{\mathrm{P}_{o}}{P_{i}} \times 100 \%
$$

Sedangkan untuk menentukan arus pengenal (nominal) motor induksi tiga fase,

$$
I_{n}=\frac{\mathrm{P}_{1}}{\sqrt{3} \cdot V \cdot . \cos \varphi}
$$

$$
\begin{array}{ll}
\text { Keterangan: } \\
\text { In } & =\text { arus nominal motor (A) } \\
\text { P1 } & =\text { daya input motor (watt) } \\
\text { P2 } & =\text { daya output motor (watt) } \\
\text { V } & =\text { tegangan line-to-line (volt) } \\
\operatorname{Cos} \varphi & =\text { faktor daya (power factor) }
\end{array}
$$

\section{F. Karakteristik Motor Induksi 3 Fase.}

Karakteristik motor listrik menunjukkan kinerja motor tersebut dalam berbagai kondisi operasi. Karakteristik motor listrik yang utama, yang perlu diperhatikan adalah :

- $\quad$ Karakteristik torsi-arus

- Karakteristik kecepatan-arus

- Karakteristik torsi-kecepatan.

Torsi di bangkitkan pada poros motor atau mesin penggerak dengan kecepatan putar n. Dari kedua besaran ini, maka dapat diketahui daya mekanis motor atau mesin penggerak tersebut. Kecapatan putaran motor $\mathrm{n}$ adalah jumlah revolusi untuk suatu periode waktu tertentu. Kecepatan putaran motor diukur dalam satuan revolusi per menit (rpm) atau revolusi per detik (rps). Kecepatan putaran motor listrik umumnya menggunakan satuan revolusi per menit (rpm). Untuk pengukuran torsi dapat digunakan tongkat penyeimbang, dimana hasil kali antara gaya dan panjang dari lengan penyeimbang merupakan torsi yang dihasilkan.

$$
T=\mathrm{Fxr}
$$

$$
\begin{array}{ll}
\text { Keterangan: } \\
\mathrm{T} & \text { : torsi }(\mathrm{Nm}) \\
\mathrm{F} & \text { : gaya (newton) } \\
\mathrm{r} & \text { : radius (meter) }
\end{array}
$$

Jika torsi yang searah jarum jam sama besar dengan torsi yang berlawanan arah jarum jam, maka tercapai posisi seimbang. Jika kedua torsi ini tidak seimbang, maka kedua lengan ini akan berputar ke arah torsi yang lebih besar. Torsi juga dibangkitkan oleh mesin listrik putar, dimana medan magnet membangkitkan garis gaya magnet (fluks) di dalam stator. Berdasarkan prinsip dasar motor, maka gaya yang dibangkitkan pada konduktor kumparan rotor yang dialiri arus adalah :

$$
T=\text { B. I. L }
$$

Gaya ini bekerja pada konduktor yang berjarak dari titik tengah poros rotor. Jika terdapat sejumlah $\mathrm{z}$ konduktor yang dialiri arus yang diberada dalam garis gaya magnet, maka akan dihasilkan torsi yang besarnya:

$$
\begin{aligned}
& T=\text { Fxr } \\
& T=\text { B. I. L }
\end{aligned}
$$

$$
\begin{array}{ll}
\text { Dimana : } \\
\mathrm{T} & \text { : torsi (Nm) } \\
\mathrm{B} & \text { : intensitas medan magnet (tesla) } \\
\mathrm{I} & : \text { arus (ampere) } \\
\ell & \text { : panjang kawat (meter) } \\
\mathrm{Z} & \text { : jumlah konduktor } \\
\mathrm{r} & \text { : radius (meter) }
\end{array}
$$

Motor akan mencapai suatu kecepatan konstan jika torsi yang dibangkitkan sama besar dengan torsi lawan (torsi pengereman) yang disebabkan oleh rotor itu sendiri, gesekan yang timbul dan beban yang digerakkan. Pada mesin listrik putar, torsi diukur dengan torsi-meter, dinamometer (cradle dynamometer) atau rem arus pusar (eddy current brake).

Untuk motor listrik, terdapat hubungan antara torsi dan kecepatan putaran motor. Kecepatan putaran $\mathrm{n}$ akan menurun seiring dengan kenaikan torsi yang dibangkitkan. Torsi di bangkitkan pada poros motor atau mesin penggerak dengan kecepatan putar. Dari kedua besaran ini, maka dapat diketahui daya mekanis motor atau mesin penggerak tersebut.

Kriteria yang penting untuk mengevaluasi dan memilih sebuah motor listrik adalah faktor daya $(\cos \varphi)$, efisiensi $(\eta)$, kecepatan putaran $(\mathrm{n})$ dan daya motor $(\mathrm{P})$. Untuk motor 3 phasa, hubungan antar variabel ini diplot dalam suatu grafik membentuk kurva beban dan kurva operasi.

\section{G. Prinsip Kerja VSD (Variable Speed Drive).}

Prinsip kerja dari VSD untuk dapat mengubah frekuensi menjadi lebih kecil atau lebih besar yaitu dengan mengubah tegangan AC menjadi tegangan DC kemudian dijadikan tegangan AC lagi dengan frekuensi yang berbeda atau dapat diatur. Untuk mengubah tegangan AC menjadi DC dibutuhkan penyearah (konverter AC - DC) dan biasanya menggunakan penyearah tidak terkendali (rectifier diode). Namun juga ada yang menggunakan penyearah terkendali (thyristor diode). Setelah tegangan sudah diubah menjadi DC maka diperlukan perbaikan kualitas tegangan DC dengan menggunakan kapasitor untuk meratakan tegangan. Kemudian tegangan DC diubah menjadi tegangan AC kembali oleh inverter. Berikut disajikan gambar rangkaian VSD. 


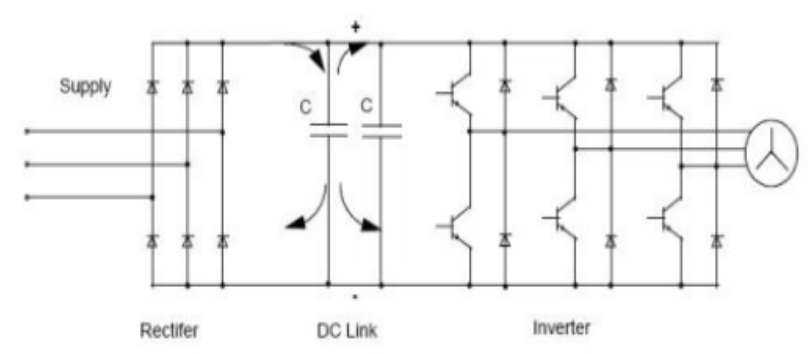

GAMBAR 4. RANGKAIAN VSD.

\section{H. Operasi VSD (Variable Speed Drive).}

Pengoperasian VSD dapat dijelaskan dengan menggunakan 4 saklar seperti ditunjukkan pada diatas. Bila saklar S1 dan S2 dalam kondisi on maka akan mengalir aliran arus DC ke beban $\mathrm{R}$ dari arah kiri ke kanan, jika yang hidup adalah sakelar S3 dan S4 maka akan mengalir aliran arus DC ke beban $\mathrm{R}$ dari arah kanan ke kiri. Inverter biasanya menggunakan rangkaian modulasi lebar pulsa (pulse width modulation - PWM) dalam proses konversi tegangan DC menjadi tegangan AC.

\section{Metode Penelitian}

Perencanaan pembuatan modul pembebanan belt conveyor menggunakan motor induksi 3 fase dengan kapasitas daya $1,5 \mathrm{~kW}$ dan pengaturan kecepatan motor menggunakan VSD Telemecanique Schneider Electric Altivar31. Sumber energi listrik dari power supply tegangan AC 220/380 V dengan frekuensi $50 \mathrm{~Hz}$.

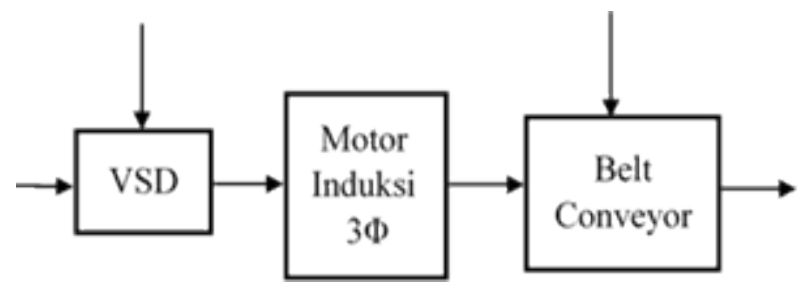

Gambar 5. Blok diagram modul percobaan.

Rangkaian Percobaan.

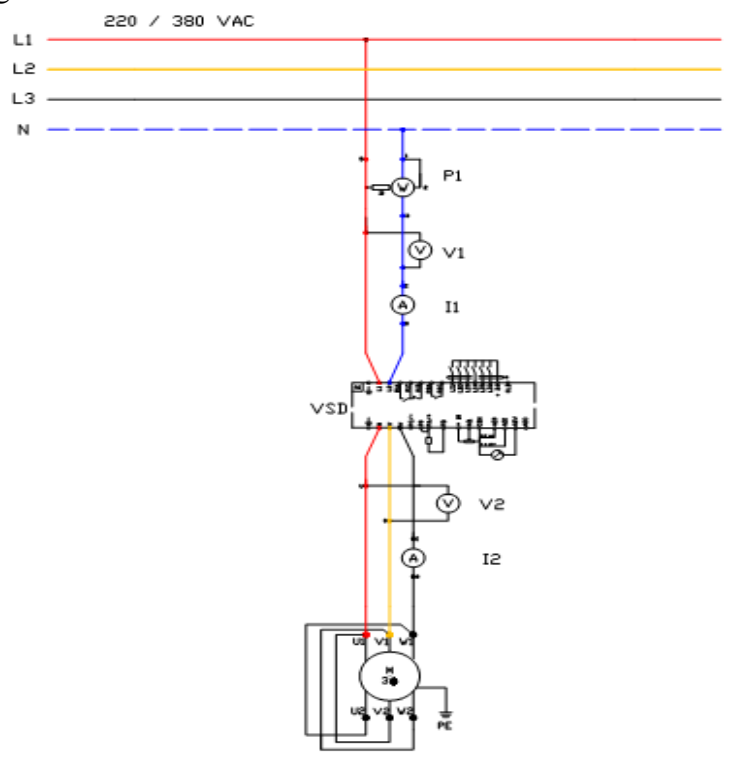

Gambar 6. Diagram rangkaian percobaan

\section{HASIL Dan PEMBahaSAN}

A. Percobaan Tanpa Beban (No Load Test).

Berdasarkan data hasil percobaan tanpa beban (no load test), diperoleh nilai torsi pada VSD adalah $3 \mathrm{Nm}$. Nilai torsi yang tidak sama dengan nol ini disebabkan oleh adanya rugi-rugi mekanik (gesek).

\section{B. Percobaan dengan Beban Konstan dan Frekuensi} Bervariasi.

\section{Pengaruh perubahan frekuensi terhadap $I_{2}$ (arus input motor).}

Dari hasil percobaan dapat dilihat bahwa semakin besar frekuensi maka arus input juga semakin besar. Hal ini sesuai dengan persamaan berikut

$$
I=\mathrm{I}_{m} \times \sin \varphi
$$

Jadi bertambahnya frekuensi maka arus input motor juga akan bertambah.

\section{Pengaruh perubahan frekuensi terhadap $P_{1}$ (daya aktif input).}

Jika arus semakin besar, maka daya yang diperlukan juga semakin besar sesuai dengan persamaan berikut :

$$
P_{1}=\sqrt{3} \times V \times I \times \cos \varphi
$$

\section{Pengaruh perubahan frekuensi terhadap $n_{r}$ (kecepatan} poros rotor).

\section{Grafik nr=f(Frekuensi)}

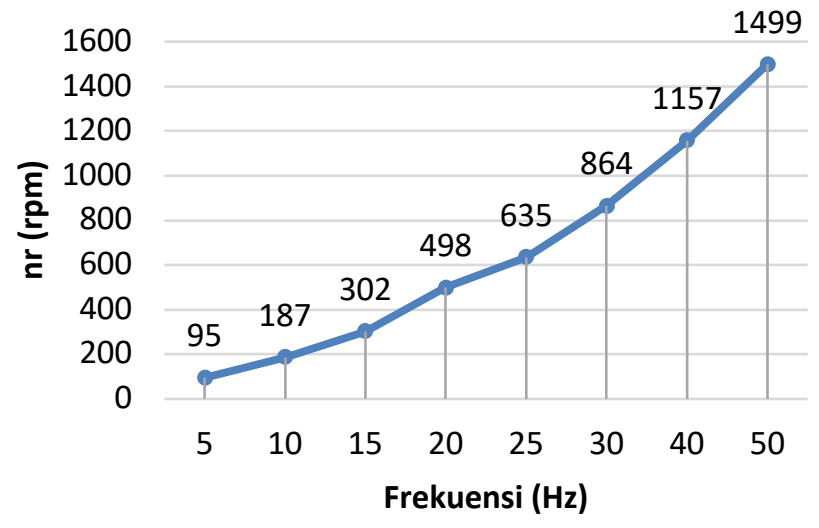

Gambar 7. Pengaruh perubahan frekuensi terhadap kecepatan poros rotor.

Berdasarkan grafik 3 dapat dilihat bahwa besar frekuensi berbanding lurus dengan kecepatan poros rotor. Hal ini sesuai dengan persamaan sebagai berikut.

$$
n_{s}=\frac{120 \times f_{1}}{P}
$$

Pada rotor berlaku hubungan:

$$
f_{2}=\frac{P\left(n_{s}-n_{r}\right)}{120}
$$

Jadi, semakin besar frekuensi jala-jala maka frekuensi arus rotor juga semakin besar sehingga kecepatan putar rotor juga semakin tinggi.

Pengaruh perubahan frekuensi terhadap slip. 
Berdasarkan rumus tersebut, besarnya nilai slip tergantung dari besar nilai $n_{s}$ dan $n_{r}$. Karena $n_{s}$ adalah pembagi dari selisih antara $n_{s}$ dan $n_{r}$, maka besar slip berbanding terbalik dengan $n_{s}$. Karena $n_{s}$ berbanding lurus dengan nilai frekuensi sumber, maka besar slip berbanding terbalik dengan frekuensi.

\section{Pengaruh perubahan frekuensi terhadap efisiensi.}

Efisiensi dapat dirumuskan dengan perbandingan daya aktif output $\left(\mathrm{P}_{2}\right)$ dengan daya aktif input $\left(\mathrm{P}_{1}\right)$. Besar frekuensi berbanding lurus dengan efisiensi, saat frekuensi bertambah, maka kecepatan stator dan kecepatan rotor bertambah, sehingga daya output juga akan bertambah. Kenaikan daya output ini lebih besar daripada daya input, sehingga efisiensinya juga akan naik.

\section{Pengaruh perubahan frekuensi terhadap v (kecepatan belt conveyor).}

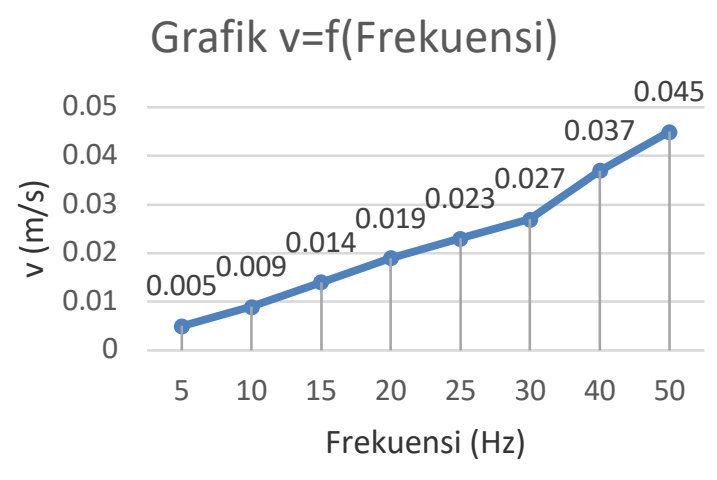

Gambar 8. Pengaruh perubahan frekuensi terhadap v.

Berdasarkan grafik 6 dapat dilihat bahwa semakin besar frekuensi maka semakin tinggi kecepatan belt conveyor. Hal ini sesuai dengan persamaan sebagai berikut:

$$
v=\frac{s x f}{\mathrm{n}}
$$

Sesuai dengan persamaa di atas dapat disimpulkan bahwa semakin besar frekuensi maka kecepatan belt conveyor juga semakin besar.

\section{Percobaan dengan Frekuensi Konstan dan Beban Bervariasi.}

Grafik dari karakteristik pembebanan belt conveyor dengan frekuensi konstanyaitu $50 \mathrm{~Hz}$ yang diatur oleh VSD dan beban bervariasi sebagai berikut.

\section{Pengaruh perubahan beban terhadap I2 (arus input} motor).

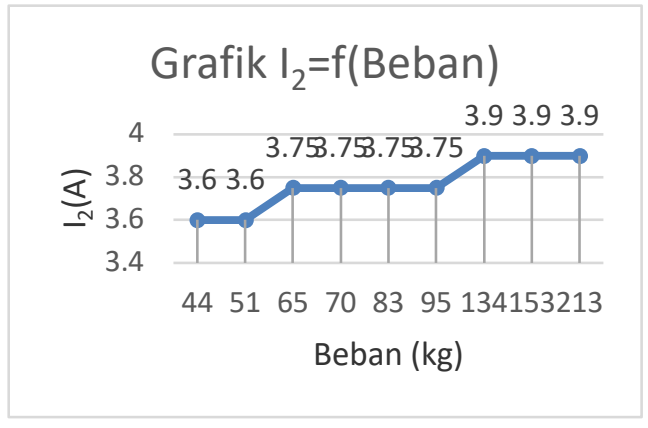

Gambar 9. Pengaruh perubahan beban terhadap $\mathrm{i}_{2}$.
Berdasarkan grafik 7 dapat dilihat bahwa semakin besar beban yang diberikan pada belt conveyor maka arus input pada motor juga semakin besar. Jadi, saat beban bertambah maka arus input motor juga akan bertambah.

\section{Pengaruh perubahan beban terhadap $P_{1}$ (daya aktif input).}

Jadi, semakin besar beban maka daya yang diperlukan motor untuk memutar rotor dengan torsi beban juga semakin besar.

\section{Pengaruh perubahan beban terhadap $n_{r}$ (kecepatan}

Saat beban bertambah, maka kecepatan motor akan semakin rendah. Hal ini disebabkan karena beban mempunyai torsi yang berlawanan arah dengan arah gerak motor, sehingga putaran motor menjadi lebih lambat. Namun, perubahan kecepatan motor cenderung konstan. Hal ini dikarenakan beban yang digunakan saat pengujian terlalu ringan bagi motor, sehingga motor seperti tidak menanggung beban terlalu berat (tidak terasa).

\section{Pengaruh perubahan beban terhadap slip.}

Saat beban bertambah, maka slip juga akan semakin besar. Hal ini disebabkan karena besar torsi beban akanberpengaruh terhadap kecepatan rotor. Semakin besar torsi beban, maka kecepatan rotor akan semakin kecil, sehingga slip semakin besar.

\section{Pengaruh perubahan beban terhadap efisiensi}

Saat beban naik, efisiensinya juga akan semakin besar. Hal ini disebabkan karena kenaikan beban akan menyebabkan kenaikan daya output. Jadi, saat beban bertambah maka efisiensi juga bertambah.

\section{Pengaruh perubahan beban terhadap v (kecepatan belt conveyor)}

Bahwa penambahan beban tidak berpengaruh terhadap kecepatan belt conveyor. Hal ini dikarenakan VSD disetting menggunakan mode nLd, dimana ketika penambahan beban (torsi variabel) kecepatan belt conveyor diusahakan cenderung konstan

\section{KesimpUlan}

Dari pengukuran dengan pembebanan belt conveyor dapat disimpulkan sebagai berikut:

1) Modul pembebanan belt conveyor ini menggunakan mode pengoperasian nLd pada VSD. Hal ini dikarenakan pada pengujian dibutuhkan kecepatan konstan pada frekuensi kerja tetap saat dibebani bervariasi. Penurunan kecepatan dari penggerak (motor) menuju belt conveyor dikonversi oleh gear box dan transmission pulley hingga mendekati $0,05 \mathrm{~m} / \mathrm{s}$. Kapasitas motor yang terlalu besar menyebabkan saat dilakukan pengujian pembebanan, motor seperti tidak menanggung beban (terasa ringan).

2) Berdasarkan hasil percobaan beban konstan dan frekuensi bervariasi dapat disimpulkan bahwa besar nilai frekuensi berbanding lurus dengan besar nilai arus input motor, daya input, kecepatan poros rotor, efisiensi, dan kecepatan belt conveyor. Namun besar nilai frekuensi berbanding terbalik dengan besar nilai slip motor.

3) Berdasarkan hasil percobaan frekuensi konstan dan beban bervariasi dapat disimpulkan bahwa besar pembebanan berbanding lurus dengan besar nilai arus 
input motor, daya input, slip, dan efisiensi. Namun besar nilai pembebanan tidak berpengaruh pada nilai kecepatan putaran rotor. Hal ini dikarenakan besar beban yang digunakan untuk pengujian terlalu kecil dibanding dengan kapasitas motor. Sehingga motor seperti tidak menanggung beban (terasa ringan). Selain itu besar nilai pembebanan juga tidak berpengaruh pada kecepatan belt conveyor (kecepatan linier) karena frekuensi pada pengujian ini adalah konstan.

\section{DAFTAR PUSTAKA}

[1]. ABB. (2004). Electrical Device - Electrical Installation Handbook Second Edition. Bergamo Italy: ABB SACE.

[2]. Arilaga, J. (2003). Power System harmonics. New York: CRC Press.

[3]. Dugan, R. C. (2004). Electrical Power System Quality - 2nd Ed. McGraw-Hill.

[4]. IEEE . (1993). IEEE 141 Recommended Practice for Electric Power Distribution for Industrial Plants. USA:

[5]. Mehta, K. (2005). Principle of Power System. S Chand; 3rd Revised edition.

[6]. Sankaran, C. (2002). Power Quality. USA: John Wiley and Son.

[7]. Schneider Electric. (1999). Guide for The Design and Production of LV Compensation Cubicles. -: Schneider Electric. 